\title{
Perbedaan Stres Persiapan Hari Raya Galungan pada Ibu Rumah Tangga dan Ibu Bekerja yang Beragama Hindu di Denpasar
}

\author{
Bagus Galih Hastosa dan Luh Made Karisma Sukmayanti S \\ Program Studi Psikologi, Fakultas Kedokteran, Universitas Udayana \\ galih_squad@yahoo.com
}

\begin{abstract}
Abstrak
Galungan merupakan hari raya keagamaan umat Hindu dalam merayakan kemenangan dharma melawan adharma. Dalam persiapan hari raya Galungan, biasanya kaum ibu baik ibu rumah tangga ataupun ibu yang bekerja adalah yang memegang tanggung jawab untuk mempersiapkan segala banten yang dibutuhkan. Mempersiapkan banten bukanlah suatu hal yang mudah karena membutuhkan keahlian, pemahaman serta waktu yang cukup untuk dapat menyelesaikan banten sehingga kegiatan mempersiapkan banten hari raya Galungan berpotensi untuk dapat menimbulkan stres pada ibu rumah tangga dan ibu bekerja. Penelitian ini bertujuan untuk mengetahui perbedaan stres persiapan hari raya Galungan pada ibu rumah tangga dan ibu bekerja yang beragama Hindu di Denpasar.
\end{abstract}

Teknik pengambilan sampel yang digunakan dalam penelitian ini adalah simple random sampling. Subjek dalam penelitian ini berjumlah 100 individu yang terdiri dari 52 ibu bekerja dan 48 ibu rumah tangga yang beragama Hindu dan berdomisili di Denpasar yang diminta untuk mengisi skala persiapan stres hari raya Galungan yang disusun berdasarkan aspek stres dari segi fisik, emosional, dan konsentrasi yang dikemukan oleh Dr. Robert J. an Amberg, Cary Cooper dan Alison Straw serta Braham. Dari 60 aitem yang disusun, 55 aitem dinyatakan valid dan 5 item gugur dengan nilai reliabilitas 0,974 . Metode analisis data yang digunakan dalam penelitian ini yaitu analisis parametrik t-test independet group. Hasil dari uji analisis data yaitu terdapat nilai signifikansi $\mathrm{p}=0,000$ yang mengindikasikan adanya perbedaan stres yang signifikan pada kedua kelompok ibu rumah tangga dan ibu bekerja, dimana ibu bekerja memiliki tingkat stres lebih tinggi dibandingkan dengan ibu rumah tangga yang beragama Hindu di Denpasar dalam persiapan hari raya Galungan.

Kata kunci : Galungan, Stres, Ibu Rumah Tangga, Ibu Bekerja

\begin{abstract}
Galungan is Hindu religious holy day in celebrating the triumph of dharma over adharma. In Galungan preparation, the mothers, housewives and working mothers, are the one who in charge to prepare all banten that needed on Galungan. Preparing Galungan's banten was not an easy task because skill, knowledge and time are needed to prepare all the banten, that why this activity had potential to make stress among housewives and working mothers. This study aimed to discover the difference Galungan preparation's stress between Hindus housewives and working mothers in Denpasar
\end{abstract}

Sampling technique used in this research was simple random samplings that were 100 subjects consisting of 52 working and mothers and 48 housewives that lived in Denpasar area, that filled the scale of Galungan Preparation's Stress that was made by stress aspect from pyshic, emotional, and concentration by Dr. Robert J. an Amberg, Cary Cooper, Alison Straw and Braham. From available 60 items, 55 items was declared dan 5 items fall with reliability value 0,974 , Method of analyzing data used in this research is the analysis of parametric t-test independet group. Results from test data analysis is that there is a significant value of $p=0.000$ which indicates a significant stress difference between both group of Hindus housewives and working mothers, which was working mothers have more stress level than housewives when working on Galungan's preparation.

Keywords : Galungan, Stress, Working Mothers, Housewives 


\section{LATAR BELAKANG}

Seiring berkembangnya zaman, seorang wanita ataupun ibu telah mendapatkan hak yang sama dengan kaum lelaki dalam bidang pendidikan ataupun kesempatan kerja. Namun dalam keluarga Bali, masyarakat Bali masih menganut budaya patriaki dimana laki-laki adalah pusat struktur keluarga dan wanita atau kaum ibu hanya sebagai subordinat. Hal ini juga terlihat dalam upacara keagamaan Hindu, dimana ibu baik yang bekerja ataupun tidak bekerja, tidak dapat melepaskan diri dari tanggung jawab sebagai "software" dalam mempersiapkan persiapan upacara keagamaan termasuk persiapan hari raya Galungan. Pekerjaan mempersiapkan banten untuk perayaan hari raya Galungan hanya ditekankan pada kaum ibu dan tidak melibatkan kaum laki-laki. Membuat banten merupakan pekerjaan yang didominasi (monopoli) bagi kaum perempuan (ibu), mengingat pekerjaan ini membutuhkan kehati-hatian, perasaan jiwa yang sabar (Darmana, 2000). Hal ini juga dijelaskan oleh Sukarsa (2005) yang mengatakan bahwa kaum ibu berperan sebagai "software" ketika mempersiapkan perayaan hari raya keagamaan karena perannya dalam mempersiapkan perangkatperangkat upacara yang sifatnya mendetail sepeti banten.

Persiapan pembuatan hari raya Galungan terdiri dari berbelanja bahan-bahan kebutuhan pembuatan banten, membuat tugelan, metetuesan, dan mejejahitan. Pembuatan banten dapat diakatakan sebagai suatu kegiatan yang kompleks. karena terlihat dari proses pemotongan dan metetuesan janur yang membutuhkan keahlian khusus agar tangan tidak terluka serta mampu membentuk pola dekoratif yang berukuran kecil serta tipis. Proses penusukan semat guna menjahit janur menjadi banten juga bukan merupakan proses yang mudah. Semat harus ditusukan secara perlahan agar janur yang memiliki tekstur tipis tidak sobek (Darmana, 2000). Segala proses persiapan hari raya Galungan ini umumnya dilakukan tiga hari sebelum perayaan Galungan yaitu pada hari Minggu dan harus dapat selesai sebelum perayaan hari raya Galungan yang selalu jatuh pada hari Rabu (Arwati, 2007). Proses pembuatan banten yang begitu kompleks membuat aktivitas persiapan hari raya Galungan sangat rawan bagi para ibu bekerja ataupun ibu rumah tangga untuk mengalami stres.

Stres berasal dari bahasa latin Stingere, yang digunakan pada abad XVII untuk menggambarkan kesukaran, penderitaan dan kemalangan (Tunjungsari, 2011). Namun saat ini stres didefinisikan sebagai adjustive demand yang membutuhkan respon adaptif dari individu (Atwater, 1983). Hal ini diperkuat oleh pernyataan Nurhendar (2007) yang mendefinisikan stres sebagai suatu tanggapan adaptif yang dibatasi oleh perbedaan individual dan proses psikologis, yaitu suatu konsekuensi dari setiap kegiatan lingkungan, situasi atau kejadian eksternal yang membebani tuntutan psikologis atau fisik yang berlebihan terhadap individu. Stres dapat mempengaruhi kondisi fisik, emosional, dan konsentrasi individu. Adapun kondisi fisik individu yang mengalami stres akan menunjukkan reaksi seperti gangguan pernapasan, gangguan tidur, kelelahan, gemetar, gangguan pencernaan, detak jatung yang meningkat, perubahan nafsu makan, otototot yang kaku, penglihatan yang semakin tajam, sedangkan kondisi konsentrasi individu cenderung mudah lupa, kacau pikiran, kebingungan, daya ingat menurun, dan melamun. Pengaruh stres terhadap kondisi emosional individu ditunjukan dengan sulitnya membuat keputusan, hilangnya kreativitas, hilangnya gairah dalam penampilan dan hilangnya minat terhadap individu lain.

Stres dapat disebabkan oleh kejadian-kejadian dalam hidup individu, seperti persiapan hari raya keagamaan. Holmes dan R.H Rahe (dalam Atwater, 1983), menyebutkan bahwa persiapan hari raya keagamaan ternyata mampu menimbulkan stres bagi individu. Hal yang sama juga dinyatakan oleh oleh (Kasser dan Sheldon, 2002) yang mengatakan persiapan hari raya keagamaan termasuk kegiatan yang mampu menyebabkan stres. Stres yang dialami ketika mempersiapkan persiapan hari raya keagamaan lebih disebabkan karena adanya tekanan finansial, dimana individu harus berbelanja berbagai perlengkapan perayaan keagamaan sedangkan uang yang dimiliki terbatas, serta keterbatasan waktu persiapan yang dimiliki sehingga menyebabkan gangguan tidur, kecemasan, pusing, dan kehilangan nafsu makan.

Keterbatasan waktu dialami oleh ibu bekerja yang ternyata hanya mendapat libur satu hari sebelum hari raya Galungan (berdasarkan surat edaran No.15/1/KEP.PBI/DPR/2013). Padahal persiapan hari raya Galungan membutuhkan waktu yang lama karena ibu harus memahami dengan benar pola dekoratif banten agar sesuai dengan filosofi Ida Sang Hyang Widhi Wasa. Keadaan ini tentu saja dapat menimbulkan tekanan waktu bagi ibu bekerja dan membuat ibu bekerja terburu-buru dalam pembuatan banten hari raya Galungan. Terburu-buru dalam pembuatan banten hari raya Galungan mampu menyebabkan janur robek ketika proses mejejahitan sehingga tidak dapat digunakan sebagai banten. Tekanan waktu ketika mempersiapkan hari raya keagamaan menurut Kasser dan Sheldon (2002) adalah salah satu faktor yang mampu menyebabkan kelelahan, kehilangan selera makan, gangguan tidur, pusing yang merupakan gejala-gejala stres pada individu. Di sisi lain, ibu bekerja berperan sebagai ibu yang mengurusi urusan keluarga seperti mempersiapkan banten yang akan digunakan keluarga dalam hari raya Galungan serta berperan sebagai pekerja yang harus menyelesaikan pekerjaan di tempat kerja. Peran ganda yang dimiliki oleh ibu bekerja sangat berpotensi dalam menimbulkan stres (Rice dalam Junita, 2011). Peran ganda pada ibu bekerja inilah yang menyebabkan terbatasnya waktu serta tenaga bagi ibu bekerja sehingga ibu bekerja tidak 


\section{STRES PERSIAPAN HARI RAYA GALUNGAN}

mampu mengerjakan pekerjaan rumah tangga termasuk mempersiapkan perayaan hari raya Galungan (J.A.C. Brown dalam Ananda, 2013).

Dalam hal waktu mempersiapkan persiapan hari raya Galungan, ibu rumah tangga tentu memiliki waktu yang lebih banyak dalam mempersiapkan banten hari raya Galungan, dibandingkan dengan ibu bekerja. Tidak adanya pekerjaan di luar rumah menyebabkan ibu rumah tangga dapat fokus dan menggunakan waktu yang dimiliki untuk mempersiapkan hari raya Galungan. Persiapan hari raya Galungan yang begitu kompleks, dimana ibu dituntut untuk dapat menyelesaikan banten dengan rapi, indah, dengan jumlah yang banyak serta adanya pekerjaan rumah tangga membuat ibu rumah tangga hanya menghabiskan waktu di rumah dan menutup diri dari pergaulan sosial yang mengakibatkan terjadinya isolasi. Isolasi yang terjadi cenderung memperkuat perasaan tidak berdaya pada ibu rumah tangga yang pada akhirnya menyebabkan ibu rumah tangga itu lebih mudah mengalami masalah-masalah psikologis (Frieze, 1978). Tidak adanya bantuan dari keluarga dalam proses persiapan hari raya Galungan mampu menimbulkan stres bagi ibu rumah tangga. Pada persiapan hari raya Galungan kaum laki-laki hanya dibebankan pada pembuatan penjor dan lawar saja, sehingga kaum laki-laki umumnya tidak ikut dalam proses pembuatan banten. Pembuatan banten hari raya Galungan memang hanya dibebankan kepada kaum ibu, dimana segala proses pembuatan banten dari pembuatan tugelan, metetuesan, sampai mejejahitan tidak dapat dilepaskan dari peran seorang ibu (Darmana, 2000). Hal ini sesuai dengan pernyataan Ayu (2009) yang menyatakan bahwa ibu rumah tangga rentan mengalami stres jika tidak ada yang membantu dalam mengerjakan pekerjaan rumah tangga.

Berdasarkan paparan diatas dapat dikatakan bahwa ibu bekerja mengalami stres persiapan hari raya Galungan dikarenakan oleh adanya konflik peran dan tekanan waktu, sedangkan ibu rumah tangga dikarenakan oleh adanya isolasi dari kehidupan sosial serta tidak adanya bantuan dalam mengerjakan pekerjaan rumah tangga. Kedua kelompok ibu bekerja dan ibu rumah tangga memiliki peluang mengalami stres persiapan hari raya Galungan namun berbeda sumber stres serta belum diketahui kelompok ibu rumah tangga ataukah ibu bekerja yang memiliki tingkat stres lebih tinggi. Perbedaan stres inilah yang akan diteliti lebih lanjut dalam penelitian ini.

\section{METODE}

\section{Variabel dan Definisi Operasional}

Variabel merupakan sesuatu yang akan diteliti dalam penelitian berupa nilai variabel yang bervariasi, yaitu angka yang berbeda-beda dari satu subjek ke subjek lain atau dari satu objek ke objek lain (Azwar, 2010). Variabel umum yang sering digunakan yaitu variabel bebas dan variabel tergantung (Umar, 2002). Variabel bebas adalah variabel yang menjelaskan atau mempengaruhi variabel lain. Variabel tergantung adalah variabel yang dijelaskan atau yang dipengaruhi oleh variabel bebas. Variabel bebas dalam penelitian ini adalah ibu rumah tangga dan ibu bekerja di Denpasar sedangkan variabel tergantung adalah stres persiapan hari raya Galungan

Definisi operasional dari Ibu rumah tangga adalah wanita yang lebih banyak menghabiskan waktu di rumah, serta mempersembahkan waktunya untuk memelihara anak-anak dan mengasuh menurut pola-pola yang diberikan masyarakat serta tidak memiliki penghasilan sendiri, sedangkan ibu bekerja adalah wanita yang selain mengurus rumah tangga juga memiliki tanggung jawab di luar rumah, baik itu kantor, yayasan atau usaha wiraswasta.

Definisi operasional dari stres persiapan hari raya Galungan adalah suatu tanggapan adaptif terhadap suatu lingkungan atau kejadian yang terjadi pada ibu rumah tangga dan ibu bekerja yang menimbulkan perasaan tidak nyaman yang terjadi ketika mempersiapkan persiapan hari raya Galungan. Stres persiapan hari raya Galungan diukur melalui tiga aspek yaitu fisik, emosional, dan konsentrasi.

\section{Responden}

Populasi adalah keseluruhan objek penelitian baik terdiri dari benda yang nyata, abstrak, peristiwa ataupun gejala yang merupakan sumber data dan memiliki karakter tertentu dan sama (Sukandarrunidi, 2004). Populasi pada penelitian ini adalah menggunakan seluruh ibu rumah tangga dan ibu bekerja yang menganut agama Hindu yang berdomisili di Denpasar, adapun kriteria sampel yang digunakan dalam menentukan subjek penelitian ini adalah subjek mempersiapkan banten perayaan hari raya Galungan, subjek telah menikah dan memiliki anak, subjek memiliki pekerjaan di luar rumah yang menghasilkan uang untuk ibu bekerja, subjek tidak memiliki sumber penghasilan sendiri untuk ibu rumah tangga.

Dalam penelitian ini peneliti menggunakan metode random sampling dengan teknik simple random sampling. Simple random sampling merupakan pengambilan anggota sampel di populasi dilakukan secara acak tanpa memperhatikan strata yang ada dalam populasi itu (Sugiyono, 2006). Sampel dirandomisasi dengan cara undian yaitu memberikan nomor pada lembar jawaban subjek dan kemudian diundi hingga mendapatkan jumlah subjek yang mencukupi. 


\section{Tempat Penelitian}

Penelitan ini dilakukan pada tanggal 30 April 2013 4 Mei 2013, dan Skala Stres Persiapan Hari Raya Galungan disebar di beberapa tempat di Denpasar seperti di Bank Mayapada, TVRI, dan di beberapa perumahan di sekitar daerah Sesetan, Renon, Teuku Umar, Gatot Subroto.

\section{Alat Ukur}

Skala pengukuran Stres Persiapan Hari Raya Galungan disusun berdasarkan aspek-aspek stres oleh Dr. Robert J. an Amberg, Cary Cooper, Alison Straw and Braham yaitu aspek fisik, emosional, dan konsentrasi. Aspek fisik mencakup indikator gangguan respirasi, gangguan tidur, gangguan pencernaan, otot-otot kaku, kelelahan, pingsan, dan perubahan nafsu makan. Sedangkan secara aspek emosional mencakup indikator perasaan bingung, cemas, jengkel, salah paham, tidak berdaya atau tidak mampu untuk melakukan apapun, gelisah, tidak menarik, kehilangan semangat, sulit membuat keputusan, hilangnya kreativitas, hilangnya gairah dalam penampilan dan hilangnya minat terhadap individu lain. Selanjutnya pada aspek yang ketiga yaitu konsentrasi mencakup indikator mudah lupa atau menurun daya ingat, kacau pikiran, sulit untuk berkonsentrasi, suka melamun berlebihan, pikiran hanya dipenuhi satu pikiran saja.

Skala Persiapan Hari Raya Galungan menggunakan skala Likert dengan menyediakan empat alternatif jawaban yaitu : Sangat Setuju, Setuju, Tidak Setuju, dan Sangat Tidak Setuju. Tidak ada pilihan jawaban ragu-ragu untuk menghindari subjek penelitian memilih jawaban netral, pada skala stres terdapat aitem favorable dan unfavorable yang memiliki persentase yang sama (Umar, 2002). Skala stres tidak menyertakan pilihan netral karena berdasarkan pertimbangan bahwa pernyataan akan memiliki arti ganda, serta jawaban ragu-ragu akan menyebabkan adanya central tendency effect yaitu kecenderungan menjawab yang ada di tengah-tengah saja. Tidak tersedianya jawaban netral maka tidak langsung subjek akan memberi jawaban yang pasti kearah setuju atau tidak setuju.

\section{Metode Pengumpulan Data}

Dalam penelitian ini pengumpulan data dilakukan melalui angket atau kuesioner. Peneliti menyebarkan satu kuesioner yaitu Skala Stres Persiapan Hari Raya Galungan yang disusun berdasarkan aspek stres fisik, emosional, dan konsentrasi dari Dr. Robert J. an Amberg, Cary Cooper, Alison Straw and Braham kepada ibu rumah tangga dan ibu bekerja.

\section{Teknik Analisis Data}

Validitas berasal dari kata validity yang mempunyai arti ketepatan dan kecermatan suatu alat ukur dalam mempunyai fungsi ukur sehingga sebuah instrumen pengukuran akan dapat dikatakan mempunyai validitas yang tinggi apabila alat pengukur suatu penelitian menjalankan fungsi ukur atau memberikan hasil ukur yang sesuai dengan maksud yang dilakukan oleh tujuan pengukuran (Azwar, 2010). Uji validitas adalah uji tentang kemampuan suatu kuesioner dalam mengukur apa yang ingin diukur. Uji validitas dilakukan dengan menghitung korelasi antara masing-masing aitem dengan skor total menggunakan rumus Pearson Product Moment. Perhitungan dilakukan secara komputasi dengan menggunakan analisis SPSS. Koefisien korelasi yang kurang dari 0,3 menunjukkan aitem pertanyaan tidak mengukur apa yang hendak diukur (tidak valid). Sebaliknya, koefisien korelasi yang lebih besar dari 0,3 menunjukkan bahwa aitem pertanyaan tersebut valid (Azwar, 2010). Dalam penelitian ini menggunakan validitas konstruk karena ingin melihat kesanggupan suatu alat ukur dalam mengukur pengertian suatu konsep (Siregar, 2013).

Selain menguji validitas, reliabilitas juga perlu diuji. Uji reliabilitas dipakai untuk melihat kekonsistenan alat ukur sehingga bila alat ukur digunakan dari waktu ke waktu akan memberikan hasil yang sama. Reliabilitas diukur menggunakan teknik alpha cronbach. Uji reliabilitas dilakukan dengan membandingkan antara koefisien alpha seluruh aitem pada masing-masing dengan 0,6. Koefisien alpha lebih besar atau sama dengan 0,6 menunjukkan yang digunakan sebagai alat ukur adalah. Sebaliknya, koefisien alpha lebih kecil dari 0,6 menunjukkan bahwa yang digunakan sebagai alat ukur tidak reliabel (Azwar, 2010).

Setelah uji validitas dan reliabilitas dilakukan, data yang terkumpul akan dianalisis dengan menggunakan Uji t. Uji $\mathrm{t}$ adalah jenis penelitian yang digunakan untuk membandingkan antara dua kelompok atau lebih dari suatu variabel tertentu. Uji t yang digunakan pada penelitian ini adalah independent samples $\mathrm{t}$ test. Metode independent samples $\mathrm{t}$ test digunakan karena dua kelompok sampel penelitian ini berasal dari distribusi sampel yang berbeda dan untuk mengetahui apakah perbedaan mean dari dua kelompok sampel penelitian signifikan secara statistik.

Dalam melakukan analisa data, ada dua uji asumsi yang harus dipenuhi, yaitu uji normalitas dan uji homogenitas. Uji normalitas pada penelitian ini menggunakan teknik statistik uji Kolmogorov Smirnov. Uji normalitas diperlukan untuk melihat apakah sampel yang diambil peneliti benarbenar mewakili populasi, sehingga nantinya hasil penelitian dapat digeneralisasikan ke populasi (Widhiarso, 2011). Bila hasil analisis uji normalitas memperoleh nilai $\mathrm{P}>0,05$ itu menandakan data yang diperoleh berdistribusi normal. Uji homogenitas digunakan untuk mengetahui apakah varians skor 
yg diukur pada kedua sampel memiliki varians yang sama atau tidak uji homogenitas menggunakan uji levene test, dengan tingkat signifikan $>0.05$ data bersifat homogen, sedangkan jika tingkat signifikan $<0.05$ data bersifat tidak homogen.

Setelah uji beda dilakukan maka selanjutnya akan dilakukan kategorisasi skor pada Skala Stres Persiapan Hari Raya Galungan. Pengkategorisasian skor dibagi ke dalam 5 kategori yaitu sangat rendah, rendah, sedang, tinggi, sangat tinggi yang bertujuan untuk menempatkan subjek ke dalam kelompok yang terpisah secara berjenjang menurut kontinum berdasarkan atribut yang diukur (Azwar, 2000).

\section{HASIL PENELITIAN}

Peneliti melakukan uji coba alat ukur penelitian untuk memastikan agar alat ukur yang dibuat pada valid dan reliabel. Terdapat sebuah skala yang digunakan pada penelitian ini yaitu Skala Stres Persiapan Hari Raya Galungan. Skala Stres Persiapan Hari Raya Galungan menggunakan skala Likert yang mencakup 60 pernyataan.yang terdiri dari tiga aspek stres yaitu fisik, emosional, dan konsentrasi. Subjek uji coba alat ukur penelitian adalah ibu-ibu yang bertempat tinggal di Jalan Teuku Umar, Sesetan dan Sidakarya dan dilakukan pada tanggal 27 Mei 2013 - 28 Mei 2013. Sampel yang digunakan pada uji coba kali ini berjumlah 60 ibu-ibu yang terdiri dari 33 ibu rumah tangga dan 27 ibu bekerja. Dalam proses pengambilan sampel, penelitian ini menggunakan random sampling, sehingga tiap subjek dalam populasi mendapatkan kesempatan yang sama untuk dapat dijadikan sampel.

Validitas tiap aitem diuji dengan menggunakan nilai corrected aitem total correlation, yaitu setiap aitem yang memiliki nilai corrected aitem total correlation lebih rendah dari 0,30 akan digugurkan (Azwar, 2010). Skala Stres Persiapan Hari Raya Galungan memiliki jumlah aitem valid sebanyak 55 aitem dan aitem tidak valid sebanyak 5 aitem dari total 60 aitem.

Pengukuran reliabilitas data menggunakan Koefisien Alpha (Cronbach dalam Azwar, 2010). Skala Kepribadian dalam penelitian ini memiliki nilai alpha $(\square) 0,974$. Nilai Alpha $(\alpha)$ sebesar 0,974 ini menunjukkan bahwa Skala Persiapan Hari Raya Galungan mampu mencerminkan 97,40 $\%$ variasi yang terjadi pada skor murni sampel yang bersangkutan sehingga dapat digunakan untuk mengukur Stres Persiapan Hari Raya Galungan

Setelah dilakukan tes validitas dan realibilitas maka, peneliti mengujikan Skala Stres Persiapan Hari Raya Galungan kepada 100 subjek yang terdiri dari 52 ibu bekerja dan 48 ibu rumah tangga untuk dilakukan uji normalitas. Uji normalitas menunjukkan bahwa Skala Stres Persiapan Hari Raya Galungan memiliki probabilitas (p) sebesar 0,067 yang berada di atas taraf signifikansi 0,05 ( $\mathrm{p}>0,05)$. Hal ini menunjukkan bahwa sebaran data pada variabel stres persiapan hari raya Galungan tidak memiliki perbedaan dengan kurva normal, sehingga sebaran data dinyatakan normal.

Hasil uji homogenitas menunjukkan bahwa varians skor variabel yang diukur pada setiap kelompok yang diuji dalam penelitian ini adalah bersifat homogen. Hal ini terlihat dari varians pada setiap kelompok penelitian memiliki nilai signifikansi dengan probabilitas (p) 0,195 atau memiliki probabilitas di atas 0,05 atau $(\mathrm{p}>0,05)$.

Tabel 1. Hasil Uji T

\begin{tabular}{|l|l|l|}
\hline 1. & Uji Homogenitas : & 1.699 \\
Nilai F & Signifikansi & 0.195 \\
\hline 2. & $\begin{array}{l}\text { Two Independent Samples } \\
\text { (Sig 2-tailed) }\end{array}$ & 0,000 \\
\hline
\end{tabular}

Tabel 1 di atas menggambarkan bahwa ketika dilakukan uji homogenitas data menghasilkan signifikansi (p) sebesar $\mathrm{p}=0,000$ atau $\mathrm{p}<0,05$ sehingga data penelitian ini dinyatakan memiliki varians yang homogen. Saat dilakukan uji hipotesis Two Independent Samples menghasilkan signifikansi ( $\mathrm{p}$ ) sebesar $\mathrm{p}=0,000$ sehingga dapat disimpulkan bahwa ada perbedaan yang signifikan antara stres persiapan galungan ibu rumah tangga dan ibu bekerja.

Tabel 2. Kategorisasi Skor Stres Persiapan Hari Raya Galungan Pada Ibu rumah Tangga dan Ibu Bekerja

\begin{tabular}{|l|l|l|l|l|}
\hline Variabel & Rentang Nilai & Kategori & $\begin{array}{l}\text { Ibu } \\
\text { Bekerja }\end{array}$ & $\begin{array}{l}\text { Ibu } \\
\text { Rumah } \\
\text { Tangga }\end{array}$ \\
\hline $\begin{array}{l}\text { Stres } \\
\text { Persiapan } \begin{array}{l}\text { Hari Raya } \\
\text { Galungan }\end{array}\end{array}$ & $175,39<\mathrm{X}$ & Sangat Tinggi & 5 orang & 0 orang \\
\cline { 2 - 5 } & $116,8 \leq \mathrm{X} \leq 175,39$ & Tinggi & 33 orang & 13 orang \\
\cline { 2 - 5 } & $89,61 \leq \mathrm{X} \leq 118,2$ & Rendah & 8 orang & 18 orang \\
\cline { 2 - 5 } & $\mathrm{X} \leq 89,61$ & $\begin{array}{l}\text { Sangat } \\
\text { Rendah }\end{array}$ & 1 orang & 2 orang \\
\hline Jumlah & \multicolumn{3}{|l|}{52 orang } & 48 orang \\
\hline
\end{tabular}

Berdasarkan tabel di atas dapat dilihat bahwa ibu bekerja yang mengalami stres persiapan hari raya Galungan sangat tinggi sejumlah 5 individu, sedangkan tidak ada ibu rumah tangga yang mengalami stres persiapan hari raya Galungan pada rentang nilai sangat tinggi. Kemudian stres persiapan hari raya Galungan pada ibu bekerja mendominasi pada kategori tinggi sejumlah 33 individu, sedangkan pada ibu rumah tangga stres persiapan hari raya Galungan mendominasi pada kategori sedang sejumlah 18 individu. 
Tabel 3. Kategorisasi Aspek Stres Persiapan Hari Raya Galungan Pada Ibu rumah Tangga dan Ibu Bekerja

\begin{tabular}{|c|c|c|c|}
\hline \multicolumn{2}{|c|}{ Kategosi Subjek } & Jumlah Subjek & Jumlah Subjek Dalam Persen \\
\hline \multirow{4}{*}{$\begin{array}{l}\text { Ibu } \\
\text { Bekerja }\end{array}$} & Fisik & 27 & 51.9 \\
\hline & Emosional & 21 & 40.4 \\
\hline & Konsentrasi & 4 & 7.7 \\
\hline & Total & 52 & 100.0 \\
\hline \multirow{4}{*}{$\begin{array}{l}\text { Tbu } \\
\text { Rumah } \\
\text { Tangga }\end{array}$} & Fisik & 15 & 31.3 \\
\hline & Emosional & 29 & 60.4 \\
\hline & Konsentrasi & 4 & 8.3 \\
\hline & Total & 48 & 100.0 \\
\hline
\end{tabular}

Berdasarkan tabel kategorisasi di atas dapat dijelaskan bahwa sebagian besar ibu bekerja mengalami gejala stres fisik sebanyak 27 ibu bekerja atau 51.9\% mengalami stres fisik lebih dominan dibanding aspek emosional dan konsentrasi. Sedangkan 21 ibu bekerja atau $40.4 \%$ mengalami stres emosional dominan dan hanya 4 ibu bekerja $7.7 \%$ mengalami stres aspek konsentrasi dominan. Dengan kata lain, aspek fisik lah yang menjadi faktor dominan pada ibu bekerja dalam penelitian keteika mempersiapkan hari raya Galungan dibanding aspek emosional dan konsentrasi.

Ibu rumah tangga mengalami gejala stres fisik yang terlihat dari sebanyak 15 ibu bekerja atau $31.3 \%$ mengalami stres fisik lebih dominan dibanding aspek emosional dan konsentrasi. Sedangkan 29 ibu rumah tangga atau $60.4 \%$ mengalami stres emosional dominan dan hanya 4 ibu rumah tangga atau $8.3 \%$ mengalami stres aspek konsentrasi dominan. Dengan kata lain, aspek fisik lah yang menjadi faktor dominan pada ibu rumah tangga dalam penelitian keteika mempersiapkan hari raya Galungan dibanding aspek emosional dan konsentrasi.

\section{PEMBAHASAN}

Berdasarkan hasil analisis perbandingan dengan menggunakan independent samples $\mathrm{t}$ test, didapat bahwa nilai signifikansi $\mathrm{p}$ adalah sebesar 0,000 ( $\mathrm{p}<0,05)$. Hal ini menunjukkan bahwa terdapat perbedaan stres persiapan hari raya Galungan pada ibu rumah tangga dan ibu bekerja, yang beragama Hindu, atau dapat disimpulkan bahwa hipotesis nol (Ho) ditolak dan hipotesis alternatif (Ha) yang diajukan dalam penelitian ini diterima.

Hasil kategorisasi skor skala Stres Persiapan Hari Raya Galungan dengan total 100 subjek menunjukan bahwa, 5 subjek dari jumlah total subjek termasuk kategori mengalami stres persiapan hari raya Galungan sangat tinggi, dalam kategori stres persiapan hari raya Galungan tinggi terdapat 46 subjek dari jumlah total subjek, sedangkan 20 subjek dari jumlah total subjek termasuk kategori mengalami stres persiapan hari raya Galungan sedang, serta 54 subjek dari jumlah total subjek termasuk kategori mengalami stres persiapan hari raya Galungan rendah, dan 3 subjek termasuk kategori mengalami stres persiapan hari raya Galungan sangat rendah. Berdasarkan paparan diatas dapat dikatakan bahwa subjek dari dua kelompok yaitu ibu rumah tangga dan ibu bekerja sama- sama mengalami stres ketika mempersiapkan hari raya Galungan. Stres yang dialami oleh kedua kelompok ibu rumah tangga dan ibu bekerja ketika mempersiapkan hari raya Galungan sesuai dengan pernyataan Holmes dan R.H Rahe (dalam Atwater, 1983), yang mengatakan bahwa persiapan upacara keagamaan adalah salah satu kejadian hidup yang mampu menyebabkan stres pada individu.

Kedua kelompok ibu bekerja dan ibu rumah tangga sama-sama mengalami stres dalam mempersiapkan hari raya Galungan, namun hasil penelitian menunjukkan bahwa kelompok ibu bekerja ternyata mengalami tingkat stres yang lebih tinggi jika dibandingkan dengan tingkat stres yang dialami oleh kelompok ibu rumah tangga. Hal ini terlihat dari hasil skor kategorisasi yang menunjukkan bahwa, kelompok ibu bekerja yang mengalami stres persiapan hari raya Galungan sangat tinggi sejumlah 5 individu, sedangkan tidak ada ibu rumah tangga yang mengalami stres persiapan hari raya Galungan. Stres persiapan hari raya Galungan pada ibu bekerja mendominasi pada kategori tinggi sejumlah 33 individu, sedangkan pada ibu rumah tangga stres persiapan hari raya Galungan mendominasi pada kategori sedang sejumlah 18 individu. Selain itu hasil kategorisasi juga menunjukkan bahwa ibu bekerja mengalami stres aspek fisik lebih dominan dibanding aspek konsentrasi dan emosional, sedangkan ibu rumah tangga mengalami stres aspek emosional lebih dominan dibanding aspek stres fisik dan konsentrasi.

Adapun alasan ibu bekerja mengalami stres fisik lebih besar dibanding aspek emosional dan konsentrasi adalah karena ibu bekerja hanya memiliki libur satu hari untuk mempersiapkan hari raya Galungan (berdasarkan surat edaran No.15/1/KEP.PBI/DPR/2013). Terbatasnya waktu yang dimiliki ibu bekerja serta adanya pekerjaan kantor yang harus diselesaikan, membuat ibu bekerja terburu-buru dalam menyelesaikan persiapan hari raya Galungan padahal proses pembuatan banten Galungan membutuhkan waktu yang memadai. Hal ini dikarenakan pembuatan banten memerlukan kehati-hatian, serta pemahaman dan penghayatan sehingga banten yang diciptakan indah serta mengandung makna filosofi Ida Sang Hyang Widhi Wasa atau Tuhan Yang Maha Esa. Persiapan hari raya Galungan yang membutuhkan waktu dalam pengerjaanya, dapat menyebabkan tekanan waktu bagi ibu bekerja yang bertanggung jawab dalam mempersiapkan banten hari raya Galungan. Hal ini senada dengan yang diungkapkan oleh Kasser dan Sheldon (2002) yang mengungkapkan bahwa persiapan hari raya keagamaan mampu memberikan tekanan waktu yang menyebabkan individu mengalami gejala-gejala stres seperti gangguan makan, kelelahan, pusing, dan gangguan tidur yang mengacu pada gejala stres aspek fisik. 
Terbatasnya waktu serta tenaga yang dimiliki oleh kaum ibu bekerja sehingga tidak dapat mengerjakan pekerjaan rumah tangga adalah salah satu dampak negatif bagi keluarga jika seorang ibu bekerja. Selain itu, ibu bekerja tentu tidak selalu berada pada saat-saat penting ketika peran ibu sehingga tidak semua kebutuhan anggota keluarga dapat dipenuhi (Brown dalam Ananda, 2013). Keadaan ini tentu berbeda dengan ibu rumah tangga yang selalu berada di tengah-tengah keluarga, dan mampu memenuhi segala kebutuhan keluarga, termasuk persiapan hari raya Galungan.

Hal ini diperkuat oleh penelitian yang dilakukan oleh Witkil \& Lanoil (dalam Junita, 2011) yang menegaskan bahwa ibu bekerja mengalami stres yang lebih besar dibandingkan dengan ibu yang tidak bekerja. Hal ini disebabkan karena kondisi fisiologis ibu serta adanya konflik peran, yakni sebagai ibu yang bekerja, sebagai isteri, sebagai ibu di rumah dan sebagai anggota suatu perkumpulan tertentu. Ibu pekerja mengalami stres yang lebih besar karena harus menjalankan tugas ditempat kerja dan di rumah. Akibatnya, ibu bekerja menderita gejala-gejala pusing, sakit punggung, radang usus besar dan ketegangan pada masa pra menstruasi. Rice (dalam Junita, 2011) juga mengatakan bahwa ibu bekerja memiliki peran ganda, dimana ibu bekerja berperan sebagai seorang ibu yang harus terlebih dahulu mengatasi urusan keluarga, suami, anak, dan hal lain yang menyangkut rumah tangga. Tetapi di pihak lain ibu juga berperan sebagai pekerja yang harus menyelesaikan pekerjaan di tempat kerja. Peranan ganda yang dimiliki oleh ibu bekerja sangat berpotensi menyebabkan ibu bekerja mengalami stres serta memiliki tingkat stres yang lebih tinggi jika dibandingkan dengan ibu rumah tangga. Townsend dkk (2000) menyatakan bahwa banyaknya peran yang dimiliki seorang ibu dapat menimbulkan efek-efek negatif yang akan memicu stres seperti berkurangnya kepuasan hidup, stres di lingkungan kerja bahkan dapat memunculkan gejala-gejala depresi.

Konflik peran yang dialami ibu bekerja yang memiliki pekerjaan di luar rumah, seperti kantor, organisasi dan yayasan tentu dapat mengalami stres di tempat kerja yang dapat mempengaruhi peran ibu bekerja di rumah saat mempersiapkan persiapan hari raya Galungan. American Psychological Association (2009) juga mengungkapkan bahwa pekerjaan di kantor sangat berpotensi untuk mengganggu pekerjaan rumah tangga. Hal ini ditegaskan oleh Handayani (dalam Junita, 2011) yang mengatakan bahwa ibu bekerja dapat mengalami strain-based conflict, dimana peran ibu bekerja di tempat kerja, jika mendapatkan tekanan atau stres dapat mempengaruhi kondisi peran ibu bekerja di rumah. Oleh karena itu, dikatakan bahwa ibu rumah tangga yang tidak mempunyai konflik peran serta memiliki waktu yang lebih luang untuk mengerjakan persiapan hari raya Galungan mengalami stres yang lebih rendah dibanding ibu bekerja.
Meskipun dikatakan ibu rumah tangga memiliki tingkat stres persiapan hari raya Galungan lebih rendah dibanding ibu bekerja ternyata ibu rumah tangga mengalami stress persiapan hari raya Galungan pada aspek emosional yang tinggi dibanding aspek konsentrasi dan emosional. Ibu bekerja juga ternyata mengalami stres emosional yang cukup tinggi yaitu sebesar $40.4 \%$ dari total subjek ibu bekerja, walaupun stres aspek fisik yang lebih banyak terjadi pada ibu bekerja. Stres emosional ketika mempersiapakan persiapan hari raya Galungan terjadi pada ibu rumah tangga dan ibu bekerja karena tidak adanya bantuan dalam mengerjakan persiapan hari raya Galungan dari pihak suami dan keluarga. Persiapan hari raya Galungan yang hanya membebankan pada kaum ibu saja, serta kedudukan ibu baik bekerja ataupun ibu rumah tangga, yang berada di bawah kaum laki-laki menyebabkan ibu tidak sulit untuk meminta bantuan pada suami dan anak-anak mereka. Bahkan di mata masyarakat Bali menganggap aneh bila laki-laki mengerjakan pekerjaan seorang wanita atau ibu, sehingga ibu makin kesulitan untuk meminta bantuan ketika mempersiapkan hari raya Galungan (Baktiari, 2003). Hal ini diperkuat oleh pernyataan Ayu (2009) yang menyatakan bahwa ibu rentan mengalami stres jika tidak ada yang membantu dalam mengerjakan pekerjaan rumah tangga.

Berdasarkan keseluruhan analisis, dapat dilihat bahwa penelitian ini telah mencapai tujuannya yaitu mengetahui perbedaan stres persiapan hari raya Galungan pada ibu rumah tangga dan ibu bekerja yang beragama Hindu di Denpasar, dimana ibu bekerja memiliki tingkat stres lebih tinggi dibandingkan dengan ibu rumah tangga dimana ibu bekerja mengalami stres fisik lebih dominan dibanding aspek konsentrasi dan emosional sedangkan ibu rumah tangga mengalami stres aspek emosional dibanding aspek konsentrasi dan fisik.

Saran praktis yang dapat dipertimbangkan berdasarkan hasil penelitian ini terbagi menjadi dua yaitu saran bagi keluarga Bali yang beragama Hindu, saran bagi ibu rumah tangga dan ibu bekerja. Sistem patriaki yang ada di dalam keluarga Bali, yang hanya memfokuskan kegiatan mejejahitan ataupun persiapan hari raya keagamaan pada kaum wanita ataupun kaum ibu, tentu dapat menimbulkan stres seperti yang disimpulkan dalam penelitian ini. Saran bagi pihak keluarga khususnya kaum laki-laki dalam menyikapi stress persiapan hari Raya Galungan pada ibu rumah tangga dan ibu bekerja adalah tidak malu untuk membantu proses mejejahitan ataupun mempersiapkan persiapan hari raya Galungan karena akan mengurangi beban stres yang dialami oleh ibu-ibu. Ibu bekerja ternyata mengalami stres persiapan hari raya Galungan yang lebih tinggi dibanding ibu rumah tangga. Maka dari itu sebaiknya para ibu bekerja disarankan untuk tidak ragu ataupun segan untuk meminta bantuan jika mendapatkan kesulitan dalam mempersiapkan hari raya 
Galungan ataupun dapat membeli banten jika dirasa tidak mampu untuk dapat menyelesaikan seluruh persiapan hari raya Galungan. Tidak hanya kaum laki-laki saja, ibu bekerja dan ibu rumah tangga juga disarankan untuk lebih dapat memaknai hari raya Galungan lebih dalam, tidak hanya sekedar kewajiban sebagai umat beragama namun perwujudan kebahagiaan dalam merayakan kemenagan dharma, sehingga persiapan hari raya Galungan tidak dirasakan sebagai tuntutan atau beban yang memberatkan melainkan sebagai yadnya atau suatu pekerjaan yang diwujudkan dengan tulus ikhlas dan penuh kegembiraan karena akan ditujukkan kepada Ida Sang Hyang Widhi Wasa.

\section{DAFTAR PUSTAKA}

Ananda, Marissa Rizky. (2013). Self-esteem Antara Ibu Rumah Tangga Yang Bekerja Dengan Yang Tidak Bekerja. Jurnal Online Psikologi, 41- 54

American Psychological Association. (2009). Stress in America 2009. http://www.apa.org/news/press/releases/stress-execsummary.pdf

Argawa, Made. 15 September, 2013. Jelang Galungan Kuningan, Harga Pisang Naik (http://beritadewata.com/Ekonomi_dan_Bisnis/Ekonomi_d an_Bisnis/Jelang_Galungan_Kuningan,_Harga_Pisang_Nai k.html)

Arwati, Ni Sri Made.(2007). Hari raya galungan. Surabaya : Paramita.

Atwater, Eastwood. 1983. Psychology of adjusment.USA : Prentice Hall

Ayu (2009). Stres kerja akibat konflik peran pada wanita bali. Indonesian Psychological Journal.

Azwar, S. (2000). Asumsi-asumsi dalam inferensi statistika. Yogyakarta: Faculty of Psychology.

Azwar, S. (2010). Penyusunan skala psikologi . Yogyakarta: Pustaka Pelajar.

Baktiari, Nyoman (2003). Perubahan Peran Wanita Bali di Desa Sukawati Sebagai Dampak Pengembangan Pasar Seni. Universitas Udayana (skripsi tidak diterbitkan)

Bisnis Bali. 23 Agustus, 2013. Jelang Galungan : Harga Janur Membungbung Tinggi. (http://www.balibisnis.com/index.php/jelang-galungan-harga-janurmembumbung-tinggi/)

Calson, D (2000). Analyzing Data Measured by Individual LikertType Aitems. Journal of Agricultural Education, 31-35

Darmana, K. (2000).Mejejahitan dan wanita Bali bagaikan mata uang dari pendekatan etnosains. Tersedia : ojs.unud.ac.id/index.php/srikandi/article/download/2895/20 64 (6 April 2013)

Dwijayanti, J. E. (1999). Perbedaan Motif Antara Ibu Rumah Tangga yang Bekerja dan yang Tidak Bekerja dalam Mengikuti
Sekolah Pengembangan Pribadi dari Jhon Robert Powers. Media Psikologi Indonesia, 14.

Fiati, R. (2012). Stres kerja pengaruhnya terhadap teknologi informasi kecerdasan intelektual, emosioal, intelligent dan motivasi ekonomi pada wanita karir.Fakultas Teknik, Universitas Muria Kudus

Frieze, I. (1978). The women and sex roles: a social psychological perspective. New York: W. W. Norton and Co.

Handoko, L. S. (2007). Apresiasi ibu rumah tangga di Surabaya mengenai penggunaan tembang populer pada iklan di media televisi. Surabaya: Universitas Kristen Petra.

Hariadja, M. T. (2001). Manajemen personalia \& sumber daya manusia cetakan Ke-15. Yogyakarta: BPFE-Yogyakarta.

Higgins, J. E, Kleinbaum, A. P., \& Miller, P. (1985). Design methodology for randomized clinical trials; family health international. North Carolina, USA: Research Triangle Park.

Junita, Audia (2011). Konflik Peran Sebagai Salah Satu Pemicu Stres Kerja Wanita Karir. Jurnal keuangan \& Bisnis, 95- 110

Kalat, James. (2005). Introduction to psychology.USA:Wadsworth Thomson Learning.

Kartono, K. (1992). Psikologi wanita: mengenal wanita sebagai ibu dan nenek. Bandung: Mandar Maju.

Kasser, Tim \& Shelldon, Kenon. (2002). What Makes For a Merry Christmas? Journal of Happiness Studies, 98-135

Kountur, R. (2004). Metode penelitian. Jakarta: PPM. Anggota Ikapi.

Noviyan, M.(2010). Hubungan antara stres dengan agresi pada ibu rumah tangga yang tidak bekerja. Depok: Fakultas Psikologi Universitas Gunadarma

Nurhendar. (2001). Sumber daya manusia. Jakarta: PT. Gramedia Pustaka Utama

Pimpinan Bank Indonesia. 10 Januari, 2013. Surat Edaran No.15?1/KEP.PBI/DPR/2013.

Pranadji, D. K., \& Nurlaela. (2009). Faktor-faktor yang Mempengaruhi Tingkat Stres pada Anak Usia Sekolah Dasar yang Sibuk dan Tidak Sibuk. Jurnal Ilmu Keluarga dan Konsumen, 2.

Riduwan \& Sunarto. (2010). Pengantar statistika: untuk penelitian pendidikan, sosial, ekonomi, komunikasi, dan bisnis. Bandung : Alfabeta

Rosmawati.(2007).Hubungan antara kondisi stres dengan persepsi kesulitan tidur pada mahasiswa. Universitas Islam Indonesia (skrispsi tidak diterbitkan).

Sandimin, L. J. (2009). Representasi Ibu Rumah Tangga dalam Serial "Desperate Housewives". Surabaya: Universitas Kristen Petra.

Sari, Novita.(2003). Pengaruh Stress Kerja dengan Motivasi Kerja dan Kinerja Karyawan Sampoerna . Universitas Airlangga.(skripsi tidak diterbitkan).

Sarwono. 2006. Metode Penelitian Kuantitatif dan Kualitatif. Yogyakarta: Graha Ilmu

Siregar, S. (2013). Statistik parametrik untuk penelitian kuantitatif. Jakarta : Bumi Aksara

Sirikanden (1995). Galungan. Denpasar : Ria

Siswanti, Y. (2006). Analisis pengaruh stres kerja dalam memediasi hubungan antara politik organisasional dengan perilaku agresif. Jurnal Siasat Bisnis, 11, 165-180 
Smet, B. (1994). Psikologi kesehatan. Jakarta: PT. Grasindo.

Soomro, R. H., Riaz, D. F., Naved, S., \& Soomro, D. F. (2012). Comparative analysis of depression among housewives and working women in bilal. Interdiciplinary Journal of Contemporary Research in Business, 3.

Sriati, Aat.(2008). Tinjauan tentang stres. Jatinangor:Universitas Padjajaran (skripsi tidak diterbitkan).

Sudantra dkk (2011). Perkawinan Menurut Hukum Adat Bali. Denpasar : Udayana University Press

Sugiyono, P. D. (2005). Metode penelitian administrasi. Bandung: Alfabeta.

Sujiti, Ni Made. (2009). Pemberdayaan wanita Bali dalam proses pembuatan dan penjualan canang sari di Pasar Badung, Denpasar Bali. Denpasar : Universitas Udayana (skripsi tidak diterbitkan).

Sukandarrumidi. (2004). Metodelogi penelitian petunjuk praktis untuk peneliti pemula. cetakan kedua. Yogyakarta: Gadjah Mada University Press.

Sukarsa, I. M. (2005). Hubungan tiga pilar agama Hindu dalam ekonomi. Denpasar: Universitas Udayana.

Supardi. (2007). Analisa stres kerja pada kondisi dan beban kerja perawat dalam klasifikasi pasien di ruang rawat inap RUMKIT TK II putri hijau . 1-98. (skripsi tidak diterbitkan).

Supratiknya, D. A. (2000). Statistik psikologi. Jakarta: Grasindo.

Suryabrata, S. (1983). Metodologi penelitian. Jakarta: PT.Raja Grafindo Persada.

Sycip, L. (1990). Working Mothers : Their Problem and Coping Strategy. Departement of Psychology University of Phillipnes.

Townsend, Aloen L, Stephens, Mary Ann Parris, \& Martire, Lynn M. (2000). Centrality of women's multiple roles: beneficial and detrimental consequences for psychological well-being. Journal of psychology and Aging. 15, 148-156

Tunjungsari, P. (2011). Pengaruh stres kerja terhadap kepuasan kerja karyawan pada kantor pusat PT. Pos Indonesia (Persero) Bandung. 1.

Umar, H. (2002). Metode riset komunikasi organisasi (cetakan pertama). Jakarta: PT. Gramedia, Pustaka Utama.

Usman, H. (2000). Pengantar statistika. Jakarta : Bumi Aksara.

Wiana, D. I. (2009). Suksmaning banten. Surabaya: Paramita

Widiharso,W (2010).Uji linieritas. Psikologi UGM.

Zaharai, \& Syahfitri. (2008). Faktor penyebab stres kerja pustakawan pada perpustakaan. Jurnal Studi Perpustakaan dan Informasi , 60-69. 